\title{
Influence of various additives on properties of concrete
}

\author{
ZalinaTuskaeva ${ }^{1, *}$, and Soslan Karyaev ${ }^{1}$ \\ ${ }^{1}$ North-Caucasian Institute of Mining and Metallurgy (STU), 44, Nikolaeva str., 362011, Vladikavkaz \\ Russia
}

\begin{abstract}
A comparative analysis of concrete samples without chemical additives and three concrete samples with additives was carried out The first sample contains the liquid additive, the other two contain the powder additive. The article aims at finding out the effectiveness of additives influence on the physical and mechanical properties of concrete and the basis for the application areas of modified types of concrete. By means of laboratory tests, the physical and mechanical properties of concrete mixtures are determined. To determine the strength characteristics of concrete samples, the IM-1250M testing machine was used. The tests were carried out under the same temperature and humidity conditions. According to the results of the experiments, the samples with the multifunctional additive "D-5" showed the best characteristics of concrete, and the samples with the dolomite flour additive were the cheapest. As a result of the experimental analysis, the effects of three additives on the strength characteristics of concrete and water resistance were determined. Cemplast and D-5 additives are highly effective modifiers of concrete and mortar. They can increase the strength by $20-40 \%$ at the age of 28 days at dosages of $1.6-6 \%$ with a decrease in water-cement ratio and a decrease of cement amount by $20 \%$. Additives highly increase the workability of the mixture, air entrainment and water resistance. While using the chemical additives an early set of the concrete design strength is observed for the construction time reducing in 7 days.
\end{abstract}

\section{Introduction}

Modern construction and architecture are inseparably connected with reinforced concrete. Only in the 20s of the XX century reinforced concrete which had been invented in the middle of the XIX century received that significance in construction that drew it out on first place in the supporting and enclosing structures.

The widespread use of reinforced concrete structures is explained by the numerous advantages of reinforced concrete - increased strength, durability, compressive strength, good resistance to weathering. The plasticity of concrete in the wet state makes it easy to manufacture products of various shapes, and the reinforcement gives it tensile strength, which concrete does not have [1]. One of the main tasks of capital residential and industrial construction is the increasing efficiency of the production. To accomplish this task, it is

\footnotetext{
${ }^{*}$ Corresponding author: tuskaevazalina@yandex.ru
} 
required to increase the quality of design solutions for reinforced concrete structures, to manufacture higher quality concrete and to reduce the construction costs. In the last decades the problems of the quality improvement, durability, concrete and reinforced concrete cost-effectiveness in construction have been successfully solved by the industry chemicalization, in particular, through the usage of various organic and inorganic compounds as special concrete additives. They essentially influence on the hardening processes, added in small quantities relative to the mass of cement, the structure of cement stone and concrete, provide an improvement in the whole set of physical and technical properties of concrete - strength, density, water resistance, frost resistance, corrosion resistance, etc. [2 and 3].

The research questions of additives efficiency on the structure formation processes, the durability of high and high strength cement concrete have not lost their actuality in spite of the fact that there are significant successes in some chemical additives expansion, first of all, superplasticizers, the expansion of their production and usage. There are also no estimates and generalizations in scientific literature which concern to the rational areas of modified concrete application with various chemical additives. In this regard, all these issues remain relevant and need to be better studied including the efficiency assessment questions of the high-strength concrete usage based on superplasticizers and organomineral modifiers in prefabricated and monolithic construction [4].

\section{Methods and materials}

The preliminary composition of the concrete mix was selected. The selection of the heavy (ordinary) concrete composition consists of the establishing the most rational correlation between the materials of the concrete (cement, water, sand, gravel). This ratio should provide the required workability of the concrete mixture for the accepted compaction method, as well as the acquisition of the specified strength of the concrete with the lowest cement consumption at the appointed time

The design procedure for the concrete composition was carried out according to the well-known methods in accordance with GOST 27006-86 "Concretes. Rules for the composition selection" and Recommendations for the composition of heavy and finegrained concrete selection (to GOST 27006-86). The concrete B25 M350 was selected with an average design strength of $327.4 \mathrm{kgf} / \mathrm{cm} 2$ for the design class of concrete.

While conducting the experimental research the main source components for concrete were used:

- Portland cement PC 500 (Voronezh branch of Eurocement Group JSC;

- Crushed stone of fractions of $5-20 \mathrm{~mm}$ was used as a large aggregate ( Ltd PROGRESS RNO-Alania);

- sand with a fineness modulus Mk $=2.8$ (Ltd PROGRESS RNO-Alania) was used as a fine aggregate.

To confirm the compliance of the declared brand of cement with the specified manufacturer, the activity of cement was determined in the following order:

1. According to GOST 30744-2001, the normal density of the cement paste (31\%) was determined using a Vika device.

2. 3 beam samples of $160 \times 40 \times 40 \mathrm{~mm}$ size were made (GOST 310.5-88 "Cements. Test methods") with subsequent determination of bending and compression strength, and the cement activity was determined using the accelerated method on its contract on the Cement-Forecast device, equal to R28 $=51 \mathrm{MPa}$. After 28 days, the samples of the beam stored in water were tested for bending and compression. The average strength value $\mathrm{R} 28=49.4 \mathrm{MPa}$ of six samples corresponds to cement grade 500 [4 and 5]. 
The prescribed concrete brand M350 (class B25). In this case, the composition of concrete: cement - $380 \mathrm{~kg}$, sand - $780 \mathrm{~kg}$, crushed stone - $1100 \mathrm{~kg}$, water - 1601 .

The concrete forms with dimensions of $10 \times 10 \times 10 \mathrm{~cm}$ were used for the laboratory tests.

Table 1. The composition of concrete mixtures for experiments.

\begin{tabular}{|l|l|l|l|l|l|}
\hline Concrete type & cement & sand & grave & water & additive \\
\hline simple & 1.52 & 3.12 & 4.4 & 0.640 & \\
\hline $\begin{array}{l}\text { withdolomite } \\
\text { flour }\end{array}$ & 1.216 & 3.12 & 4.4 & 0.510 & 0.484 \\
\hline withD - 5 & 1.216 & 3.12 & 4.4 & 0.510 & 0.046 \\
\hline withCemplast & 1.216 & 3.12 & 4.4 & 0.510 & 0.046 \\
\hline
\end{tabular}

They replaced the concrete mix for each composition and lay in layers in a mold with compaction and vibration (fig.1.) $[6,7]$

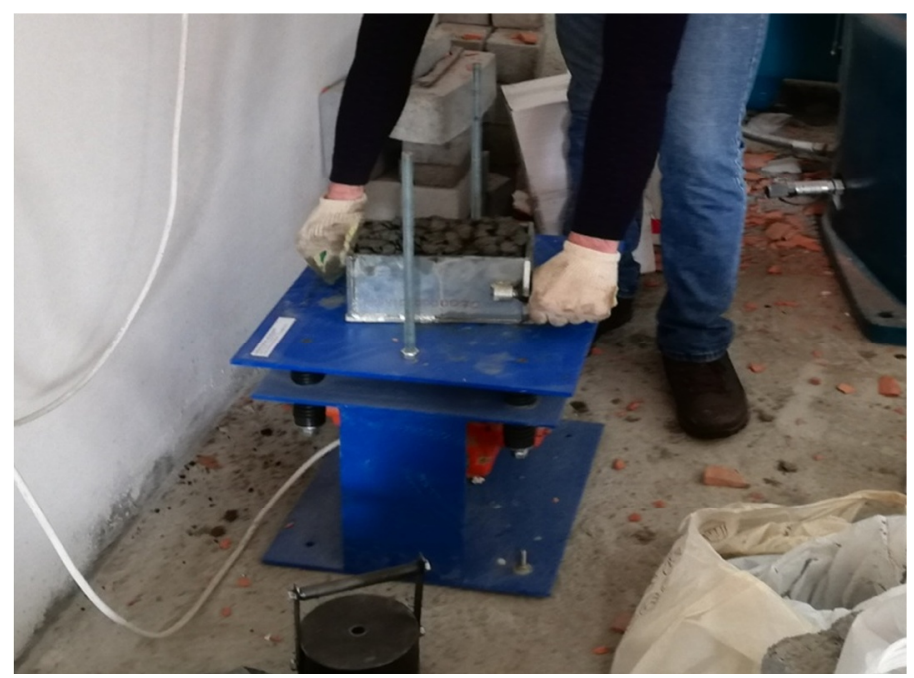

Fig. 1. The compaction of the concrete mix.

Figure 2 shows the ready concrete samples after vibration. 


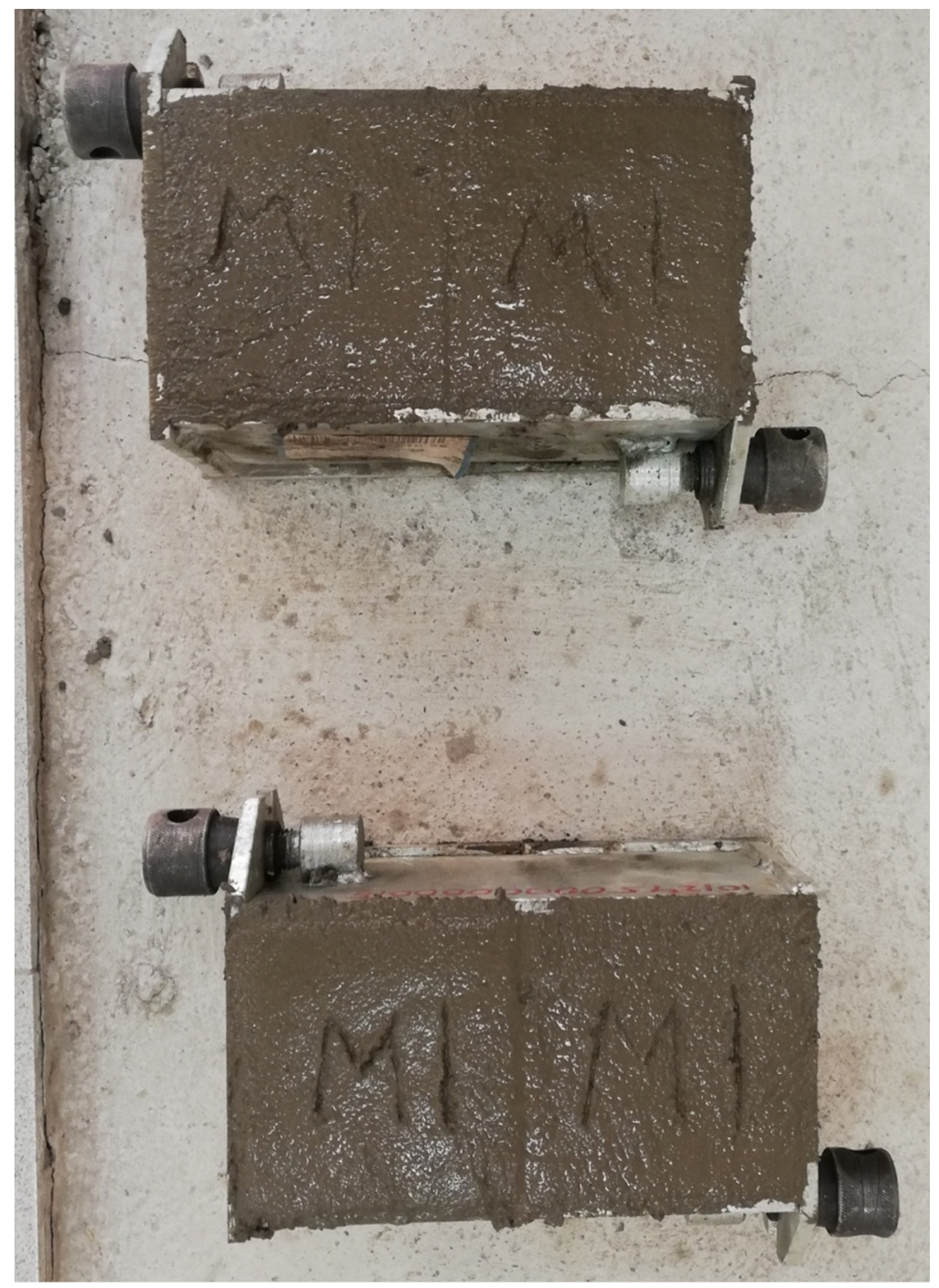

Fig. 2. Ready concrete samples after vibration.

The moment of the concrete sample destruction on a testing machine is shown on Figure 3 


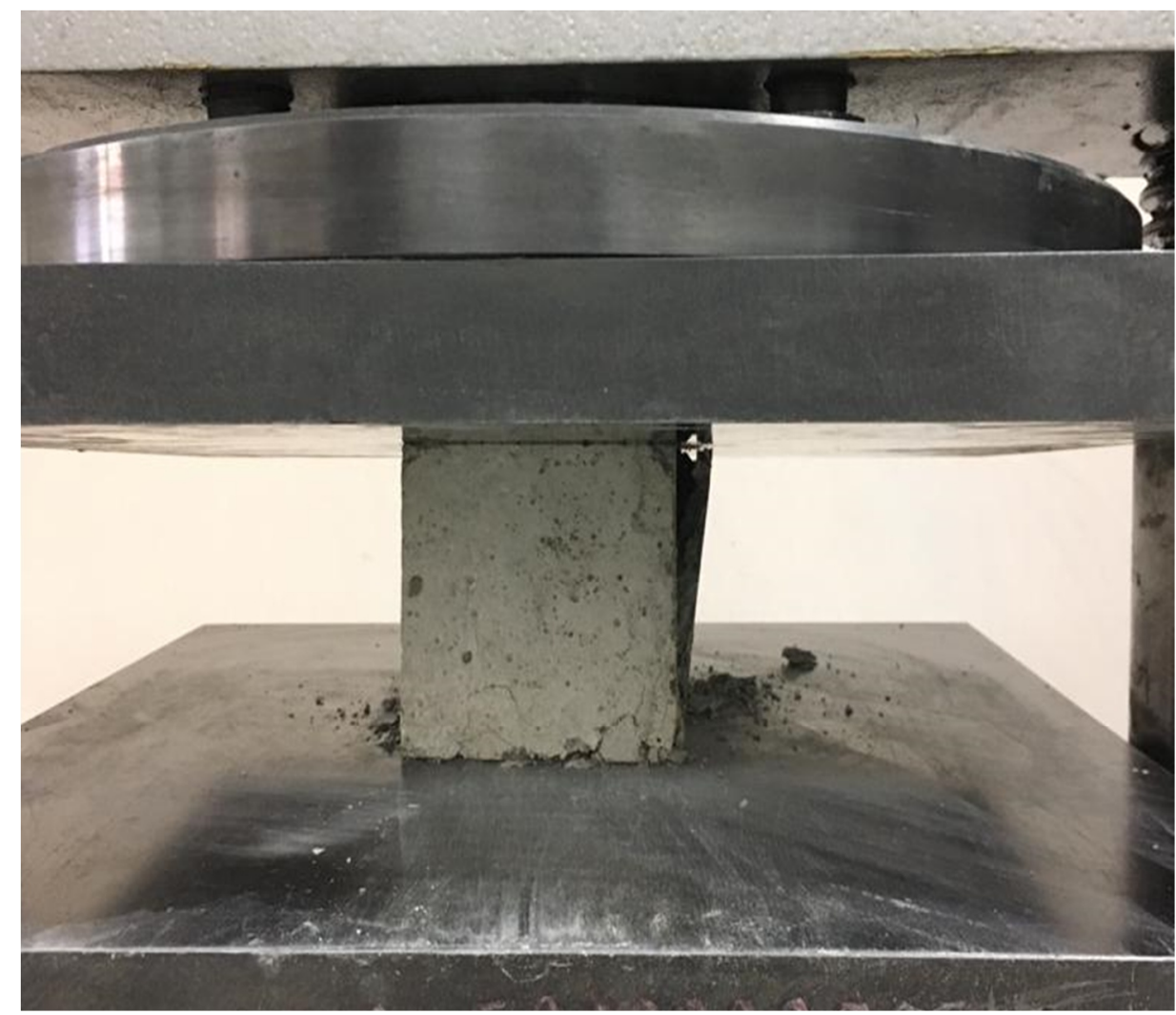

Fig. 3. The moment of the concrete sample destruction.

\section{Results of research}

Tables 2, 3 shows the determination of the concrete samples strength.

Table 2. The compression test results of concrete samples (on the $7^{\text {th }}$ day).

\begin{tabular}{|c|c|c|c|c|c|c|c|c|}
\hline \multirow{2}{*}{$\begin{array}{c}\text { Concrete } \\
\text { type }\end{array}$} & \multicolumn{3}{|c|}{ Sizes } & \multirow{2}{*}{$\begin{array}{c}\text { Weight } \\
\text { g. }\end{array}$} & \multirow{2}{*}{$\begin{array}{c}\text { density } \\
\mathrm{g} / \mathrm{cm}^{3}\end{array}$} & \multirow{2}{*}{$\begin{array}{l}\text { Destructive } \\
\text { loadtf. }\end{array}$} & \multirow{2}{*}{$\begin{array}{l}\text { Strength } \\
\mathbf{k g s} / \mathrm{cm}^{2}\end{array}$} & \multirow{2}{*}{$\begin{array}{l}\text { Averag } \\
\text { strength } \\
\text { kgs/cm }\end{array}$} \\
\hline & $\mathrm{L}$ & W & $\mathrm{H}$ & & & & & \\
\hline \multirow{2}{*}{ simple } & 10 & 10 & 10 & 2462 & 2.462 & 22.40 & 212.8 & \multirow{2}{*}{212.325} \\
\hline & 10 & 10 & 10 & 2470 & 2.470 & 22.30 & 211.85 & \\
\hline \multirow{2}{*}{$\begin{array}{l}\text { withdolomite } \\
\text { flour }\end{array}$} & 10 & 0 & 10 & 2426 & 2.426 & 29.90 & 284.05 & \multirow{2}{*}{269.99} \\
\hline & 10 & 10 & 10 & 2412 & 2.412 & 26.94 & 255.93 & \\
\hline \multirow[b]{2}{*}{ with «D-5» } & 10 & 10 & 10 & 2476 & 2.476 & 32.75 & 311.25 & \multirow[b]{2}{*}{301.88} \\
\hline & 10 & 10 & 10 & 2496 & 2.496 & 30.79 & 292.505 & \\
\hline \multirow{2}{*}{$\begin{array}{c}\text { with } \\
\text { «Cemplast» }\end{array}$} & 10 & 10 & 10 & 2324 & 2.324 & 21.95 & 208.525 & \multirow{2}{*}{211.97} \\
\hline & 10 & 10 & 10 & 2320 & 2.320 & 22.675 & 215.41 & \\
\hline
\end{tabular}


Table 3. The compression test results of the samples (on the $28^{\text {th }}$ day).

\begin{tabular}{|c|c|c|c|c|c|c|c|c|c|}
\hline \multirow{2}{*}{ Concrete type } & \multicolumn{3}{|c|}{ Sizes } & \multirow{2}{*}{$\sum_{\overrightarrow{0}}^{\dot{00}}$} & \multirow{2}{*}{ 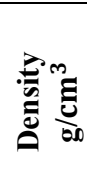 } & \multirow{2}{*}{ 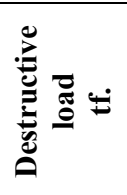 } & \multirow{2}{*}{ 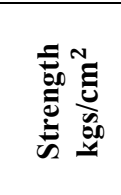 } & \multirow{2}{*}{ 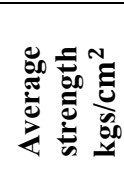 } & \multirow{2}{*}{ 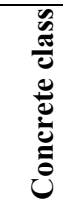 } \\
\hline & $\mathbf{L}$ & W & $\mathbf{H}$ & & & & & & \\
\hline \multirow{2}{*}{ simple } & 10 & 10 & 10 & 2462 & 2.462 & 34.82 & 330.8 & \multirow{2}{*}{333.0} & \multirow{2}{*}{$\mathrm{C} 25$} \\
\hline & 10 & 10 & 10 & 2470 & 2.470 & 35.28 & 335.2 & & \\
\hline \multirow{2}{*}{$\begin{array}{l}\text { With dolomite } \\
\text { flour }\end{array}$} & 10 & 10 & 10 & 2426 & 2.426 & 36.84 & 349.98 & \multirow{2}{*}{350,84} & \multirow{2}{*}{$\mathrm{C} 25$} \\
\hline & 10 & 10 & 10 & 2412 & 2.412 & 37.02 & 351.69 & & \\
\hline \multirow{2}{*}{ with «D-5» } & 10 & 10 & 10 & 2476 & 2.476 & 42.98 & 408.31 & \multirow{2}{*}{406.17} & \multirow{2}{*}{$\mathrm{C} 30$} \\
\hline & 10 & 10 & 10 & 2496 & 2.496 & 42.53 & 404.035 & & \\
\hline \multirow{2}{*}{ with«Cemplast» } & 10 & 10 & 10 & 2324 & 2.324 & 34.31 & 325.94 & \multirow{2}{*}{328.0} & \multirow{2}{*}{$\mathrm{C} 25$} \\
\hline & 10 & 10 & 10 & 2320 & 2.320 & 34.74 & 330.06 & & \\
\hline
\end{tabular}

Figure 4 shows a graph of the additives effect on the concrete strength.

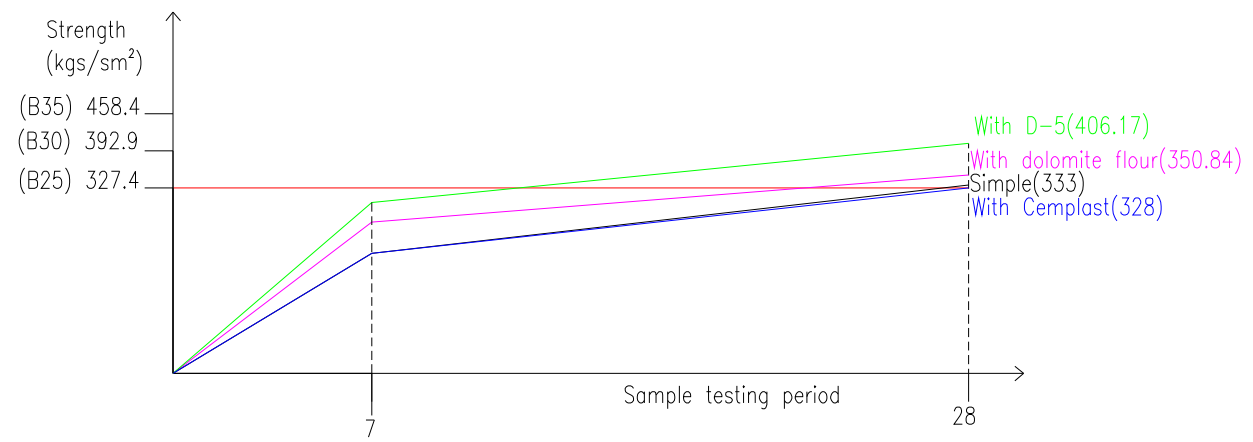

Fig. 4. Graph of the additives effect on the concrete strength.

According to GOST 12730.5-84 "Concretes. Methods of water resistance determination" the water resistance of the samples by the accelerated method of its breathability was determined. 6 cubes with $150 \mathrm{~mm}$ ribs of control concrete and concrete with additives were made to determine the water resistance.. The tests were carried out with the help of an "Agama" type device and a VIP permeability measurer 1.3.

Figure 5 shows a device schematic diagram which determines the air permeability of the concrete surface layers.

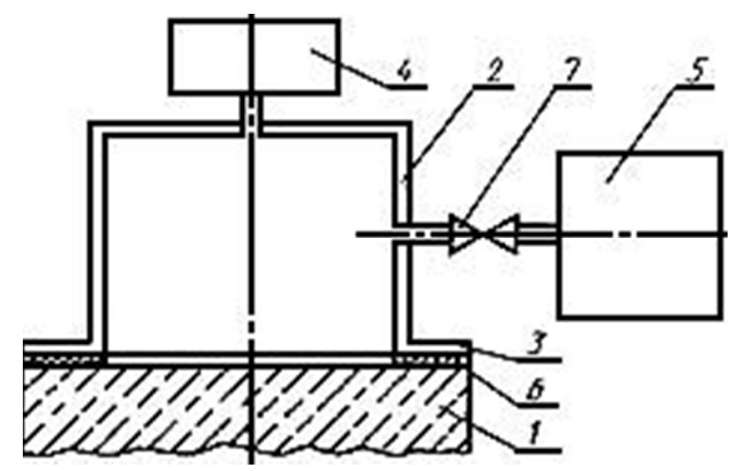

Fig. 5. Schematic diagram of a device for determining the air permeability of the concrete surface layers ( 1 concretesample; 2-cameradevice; 3 -cameraflange; 4 - vacuumgauge; 5 - vacuumpump; 6 sealingmastic; 7 - valve). 
The principle of the devices operation is based on determining the time of the vacuum pressure drop previously created in the vacuum chamber of the device, the cavity of which has airtight contact through the mastic with the surface of the test material. The pressure drop in the chamber is due to the filtration of ambient air into it through the pores and defects of the material. The rate of pressure change depends on the parameter of the material breathability or the inverse value of the material resistance to air penetration. Physical - mechanical properties of concrete are pointed in the table 4 .

Table 4. Physical - mechanical properties of concrete.

\begin{tabular}{|c|c|c|}
\hline $\begin{array}{l}\text { Concrete breathability } \\
\text { parameter,sm/s }\end{array}$ & $\begin{array}{l}\text { Concrete resistance to air } \\
\text { penetration, s/sm }\end{array}$ & $\begin{array}{l}\text { Concrete brand to } \\
\text { water resistance }\end{array}$ \\
\hline $0.325-0.224$ & $3.1-4.5$ & 2 \\
\hline $0.223-0.154$ & $4.6-6.5$ & 4 \\
\hline $0.153-0.106$ & $6.6-9.4$ & 6 \\
\hline $0,105-0.0728$ & $9.5-13.7$ & 8 \\
\hline $0.0727-0.0510$ & $13.8-19.6$ & 10 \\
\hline $0.0509-0.0345$ & $19.7-29$ & 12 \\
\hline $0.0344-0.0238$ & $29.1-42.0$ & 14 \\
\hline $0.0237-0.0164$ & $42.1-60.9$ & 16 \\
\hline $0.0163-0.0113$ & $61-88.5$ & 18 \\
\hline $0.0112-0.00077$ & $88.6-130.2$ & 20 \\
\hline
\end{tabular}

During the test, the sealing mastic bundle with a diameter of at least $6 \mathrm{~mm}$ is laid on the chamber flange along its midline and the ends are connected. The test surface is cleaned from the cement paste film with a wire brush. The chamber is mounted with a flange on the lower (according to the molding conditions) surface of the sample and a vacuum of $0.7 \mathrm{~kg} / \mathrm{cm} 2$ is created in the chamber cavity. Further, the stopwatch determines the time of pressure drop to $0.65 \mathrm{~kg} / \mathrm{cm} 2$. The obtained rates of the pressure drop time are recorded in the order of their increase and the arithmetic mean value of two average samples (third and fourth) is determined as a parameter characterizing the air permeability of concrete in the series.

Figure 6 shows water resistancegradesof concrete samples

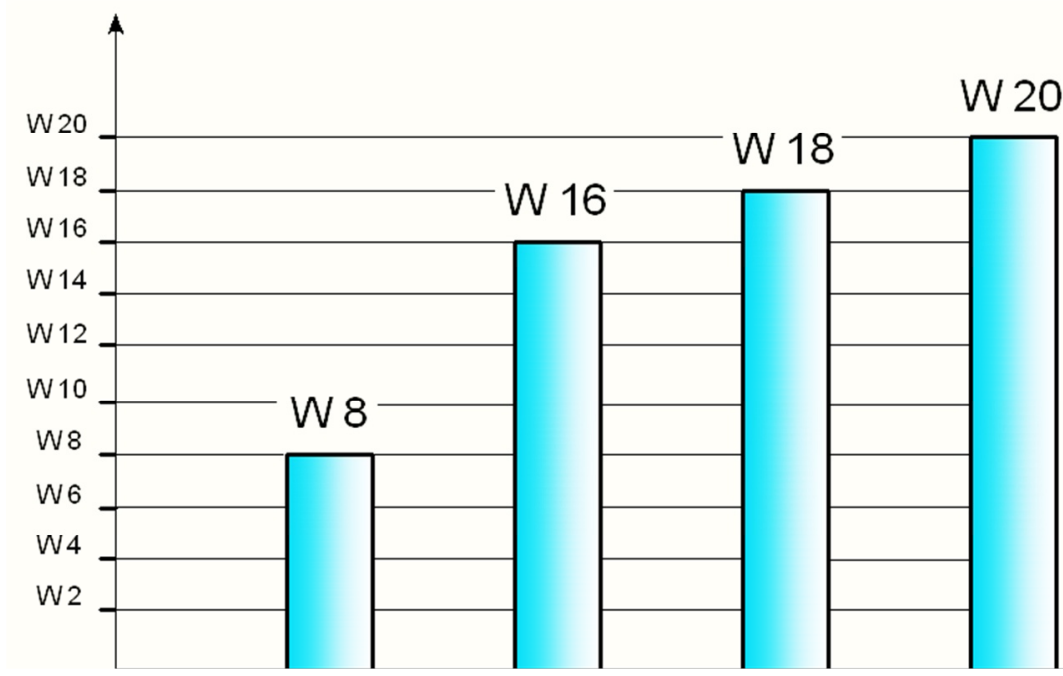

Fig. 6. Water resistancegradesof concrete samples. Where: W8 - simpleconcrete, W16 - samples with Cemplast, W18 - with dolomite flour, W20 - with additive D-5. 


\section{Conclusion}

The appropriate and purposeful usage of the concrete additives allows the engineers of concrete plants to modify fresh and solid concrete properties according to different aims of the construction industry. At the same time, it allows to realize the highly- qualified and durable concrete production in various climate conditions [8]. The most important quality of concrete construction will be its high quality and durability in future. From this site the additives usage in concrete is necessary and this method has become the integral part of all concrete technologies [9].

The application of additive should be economically worthwhile it cannot allow the increase of concrete cost.

As a result of the experimental analysis the influence of additives on concrete durability characteristics and water resistance was determined.

Additives Cemplastand D-5 and dolomite flour are high- effective modifications of concrete and construction solutions [10]. They can increase strength by $20-40 \%$ at the age of 28 days at dosages of $1.6-6 \%$ with a decrease in water-cement ratio and a decrease in the amount of cement by $20 \%$. Additives greatly increase mixture workability, frost resistance, air entrainment, water resistance [11]. While using chemical additives it is observed an early set of design concrete strength on the $7^{\text {th }}$ day that leads to the reduction of construction period [12 and13].

It is appropriate to use dolomite flour and D-5 in constructions which have complex requirements on strength, water and frost resistance.

Considering a relatively high cost of Cemplast and not high rates of strength and water resistance the application of this additive can be justified only in concrete which has high strength requirements [14 and15].

\section{References}

1. J.L. Vincent, C.P. Gana Jack, M.C. ChengaIrene, Journal of Cleaner Production 229, 582-597 (2019) https://doi.org/10.1016/j.jclepro.2019.05.035

2. S. Demisa Vagelis, G. Papadakisb, Journal of Building Engineering 26, 100876 (2019) https://doi.org/10.1016/j.jobe.2019.100876

3. I. Sadrinejad, R. Madandous, M. Mohammad Ranjbar, Construction and Building Materials 178, 72-82 (2018) https://doi.org/10.1016/j.conbuildmat.2018.05.145

4. R. Ibragimov, R. Fediuk, Construction and Building Materials 226, 839-848 (2019) https://doi.org/10.1016/j.conbuildmat.2019.07.313

5. Yu-Hang Wang, Jie Yu Jie-Peng Liu, Bao-Xu Zhou, Y. Frank Chen, Journal of $\begin{array}{llll}\text { Constructional Steel Research } & 105667\end{array}$

(2020) https://doi.org/10.1016/j.jcsr.2019.06.004

6. C. Cosgun, A. Murat Turk, A. Mangir, T. Cosgun, G. Kiyma, Engineering Failure Analysis 109, 104247 (2020) https://doi.org/10.1016/j.engfailanal.2019.104247

7. J.Q. Bao, X. Long, K.H. Tan, C.K. Lee, Engineering Structures 56, 2076-2082 (2013) https://doi.org/10.1016/j.engstruct.2013.08.025

8. Q. Huy Vu, G. Pham, A. Chonier and others, Construction and Building Materials 216, 450-467 (2019) https://doi.org/10.1016/j.conbuildmat.2019.04.263

9. D. Nagrockienè, G. Girskas, G. Skripkiunas, Construction and Building Materials 135, 37-42 (2017) https://doi.org/10.1016/j.conbuildmat.2016.12.215

10. Z. He, L. Hu, Y. Li, J. Hu, Y. Shao, Construction and Building Materials 186, 276-286 (2018) https://doi.org/10.1016/j.conbuildmat.2018.06.228 
11. F.J. Rubio-Hernández, A. Adarve-Castro, J.F. Velazquez-Navarro, N.M. Paez-Flor, R. Delgado-Garcia, Construction and Building Materials 235, 117744 (2020) https://doi.org/10.1016/j.conbuildmat.2019.117744

12. S. Das, S. Ray, S. Sarkar, Construction and Building Materials 233, 117214 (2020) https://doi.org/10.1016/j.conbuildmat.2019.117214

13. D. Nekesa Khaemba, A. Azam, T. Long See, A. Neville, F. Motamen Salehi, Journal Pre-proof 106243 (2020) https://doi.org/10.1016/j.triboint.2020.106243

14. R.M. Mors, H.M. Jonkers, Industrial Crops and Products 106, 97-104 (2017) https://doi.org/10.1016/j.indcrop.2016.10.037v

15. J. Lok, G. Lim, S.N. Raman, F.-Ch. Lai, M. Fauzi Mohd Zain, R. Hamid, Journal of Cleaner Production 171,

https://doi.org/10.1016/j.jclepro.2017.09.143

(2018) 